\title{
Analysis of the cheese components' influence on the dehydration process under reduced pressure
}

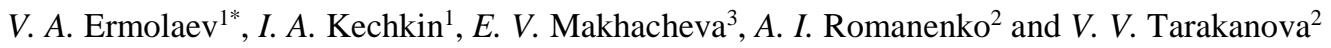 \\ ${ }^{1}$ Department of Commodity Science and Expertise Plekhanov Russian University of Economics, 117997 Moscow, Russia \\ ${ }^{2}$ K.G. Razumovsky Moscow State University of technologies and management (the First Cossack University), 109004 Moscow, Russia \\ ${ }^{3}$ Department of Technology and Organization of Food Production, Faculty of Business, Novosibirsk State Technical University (NSTU), \\ 630073 Novosibirsk, Russia
}

\begin{abstract}
This work is aimed at studying the influence of various components' content on the process of vacuum dehydration. It was found that with an increase in the proportion of fat in dry matter from 10 to $20 \%$, the duration of disinfection increases by $4 \%$. The further grows of the fat proportion from 20 to 50 increases the process duration by $54 \%$. It was revealed, when cheeses, with the fat proportion equal from 10 to $50 \%$, a change their fat proportion by $1 \%$, the duration of dehydration decreases by 4.25 minutes, and the drying rate grows by $0.0065 \% / \mathrm{min}$. It has been discovered that with an increase in the table salt concentration with the same mass fraction of cheese moisture 53-55\%, a decrease in the rate of dehydration is observed as well. In the period with a constant drying rate at a concentration of sodium chloride of $1 \%$, the drying speed is $0.98 \% / \mathrm{min} ; 2 \%-0.8 \% / \mathrm{min} ; 3 \%-0.72 \% / \mathrm{min} ; 4 \%-0.54 \% / \mathrm{min}$. The amount of water activity in cheeses was investigated. It was established that with an increase in the concentration of table salt from 1 to $4 \%$, the water activity of cheese before drying changes by 0.131 ; after drying - by 0.174 .
\end{abstract}

\section{Introduction}

Improving the existing technologies and developing new effective ones for processing agricultural raw materials has always been one of the urgent tasks of the food industry [1-10]. As for dairy products, cheese occupies a special place. The uniqueness of this product lies in its special chemical composition, which includes a whole range of biologically active components that have a beneficial effect on human health [11-16]. However, the specificity of the physico-chemical composition determines the low shelf life and the need to use refrigeration equipment for its storage [17-22].

One of the possible ways of preserving and processing this type of material is vacuum dehydration. Properly selected modes provide high efficiency of this process [23-25]. Factors influencing the vacuum drying process are the modes of the drying unit itself (heating temperature, method of supplying heat, residual pressure, etc.), as well as the geometric characteristics of the product itself and its physicochemical composition [26-31].

\section{Materials and methods}

For the drying process, an installation was used, the scheme of which is shown in Figure 1.

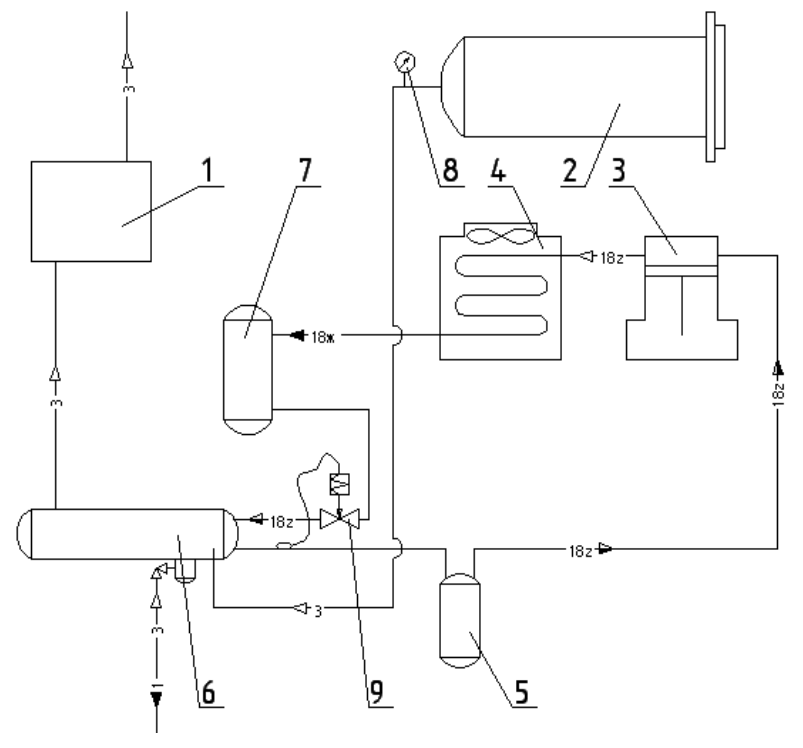

Fig. 1. Scheme of an experimental vacuum drying installation: 1 - vacuum pump, 2 - working chamber, 3 - compressor, 4 - capacitor, 5 - liquid separator, 6 - desublimator, 7 receiver, 8 - vacuum gauge, 9 - thermostatic expansion valve

The experimental installation includes a drying chamber 2, where a product is loaded into a pallet mounted on a weight sensor. In addition, the chamber has two infrared lamps, as well as temperature and pressure sensors. The air from the chamber is evacuated by a vacuum pump 1 . The air passes through the desublimator 6; the moisture from the air is frozen on the

* Corresponding author: ermolaevvla@ rambler.ru 
evaporator of the refrigerating machine. This is necessary to reduce the load on the vacuum pump. The refrigeration unit consists of a compressor 3 , an air capacitor 4, a liquid separator 5, a receiver 7 , an evaporator and a thermostatic valve 9 .

The installation works in the following way. The test sample is loaded into a drying chamber, which is hermetically sealed with a lid. Further, a vacuum pump is introduced to lower the pressure in the chamber. When the set residual pressure is set in the chamber, infrared heating lamps are turned on and vacuum drying begins. The chamber is equipped with temperature, mass and pressure sensors, which allow controlling the process of moisture removal. Signals from the sensors through the converter come to the computer, where the data are continuously registered.

\section{Results and Discussion}

The purpose of the current work was to study the influence of the cheese components' content on the process of vacuum dehydration of cheeses.

The product was dried at a heating temperature $(60 \pm 3){ }^{\circ} \mathrm{C}$, a residual pressure of $2-3 \mathrm{kPa}$ and a heat flow density of $5.5 \pm 0.3 \mathrm{~kW} / \mathrm{m}^{2}$. Before the product loading into the chamber, the cheese was cut into cubes measuring 10x10x10 mm. Cheese of the following brands was used: "Rizhskiy", "Gollandskiy" and "Kostromskoy".

The duration of vacuum drying for cheeses with a layer thickness of $10 \mathrm{~mm}$ was 200 minutes, and with a layer thickness of $30 \mathrm{~mm}-300$ minutes.

Figure 2 shows graphs of the speed of cheese drying.

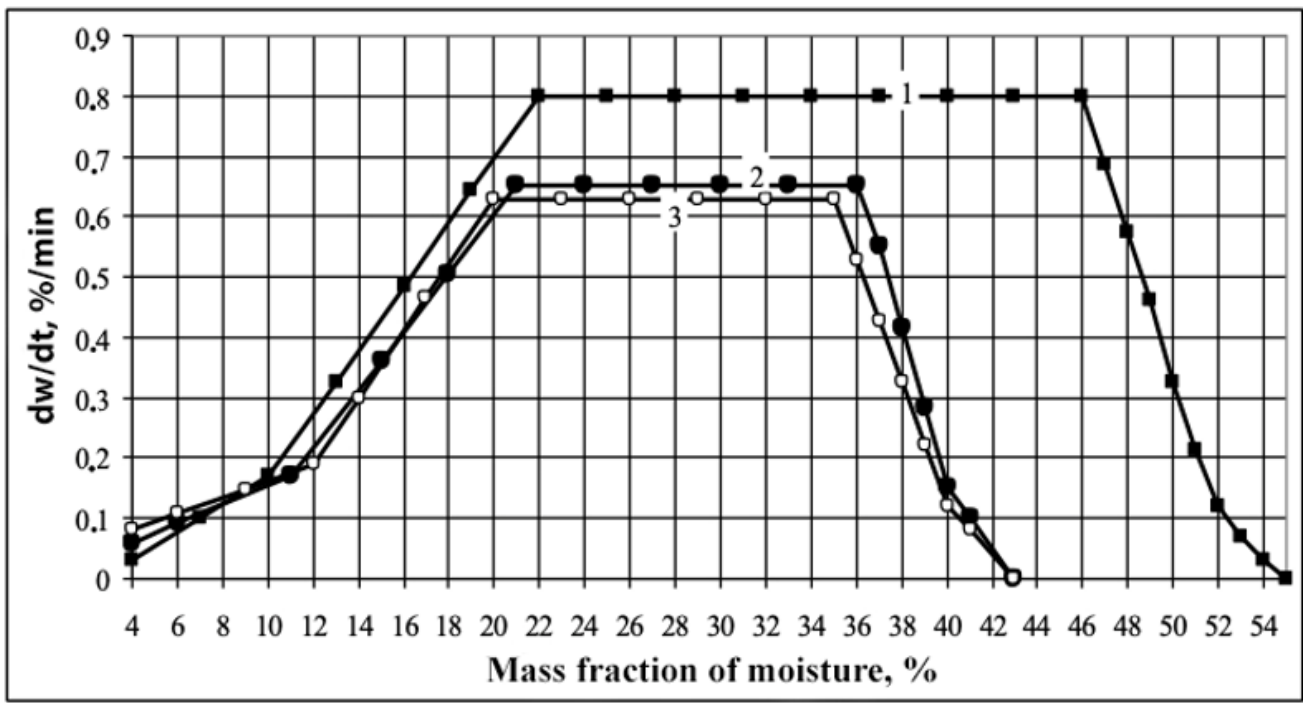

Fig. 2. The speed of cheese drying, depending on the mass fraction of moisture: 1 - "Rizhskiy"; 2 - "Gollandskiy"; 3 "Kostromskoy".

According to the presented graphs, three periods of drying speed can be distinguished:

The period of increasing drying speed. For "Kostromskoy" and "Gollandskiy" cheeses, this period lasts up to a moisture content of 35-36\%, for "Rizhskiy" cheese - up to a moisture content of $46 \%$. At this stage, about $16-18 \%$ of the moisture is removed.

The period of constant drying speed. During this period, about $24 \%$ of moisture is removed from "Rizhskiy" cheese and $15 \%$ from "Gollandskiy" and "Kostromskoy".

The period of the falling drying speed. At this stage, $16-18 \%$ moisture is removed.

The highest rate of moisture removal occurs in the second period and amounts $0.8,0.65$ and $0.64 \% / \mathrm{min}$ for "Rizhskiy", "Gollandskiy" and "Kostromskoy" cheeses respectively. The higher drying speed of the "Rizhskiy" cheese is explained by its high moisture content. Thus, with an increase in the mass fraction of moisture in cheeses, the dehydration rate and the duration of the period of constant drying speed increase.
Figure 3 shows the dependence of the process duration of cheese vacuum dehydration on the mass fraction of fat.

It was found that with an increase in the mass fraction of fat in dry matter from 10 to $20 \%$, the duration of dehydration process increases by $4 \%$. With a further increase in the mass fraction of fat from 20 to $50 \%$, the drying time increases by $54 \%$.

This phenomenon occurs due to the hydration properties of cheeses. Water builds a shell around the globular fat. The shell of globular fats is able to bind practically the same amount of moisture as the proteins do themselves.

In other words, with an increase in the mass fraction of fat, there is an increase in the binding energy of water, thereby increasing the duration of dehydration. Moreover, with an increase in the mass fraction of fat, the rate of moisture removal decreases.

Figure 4 shows a graph of the dependence of the cheese drying speed on the mass fraction of fat. 


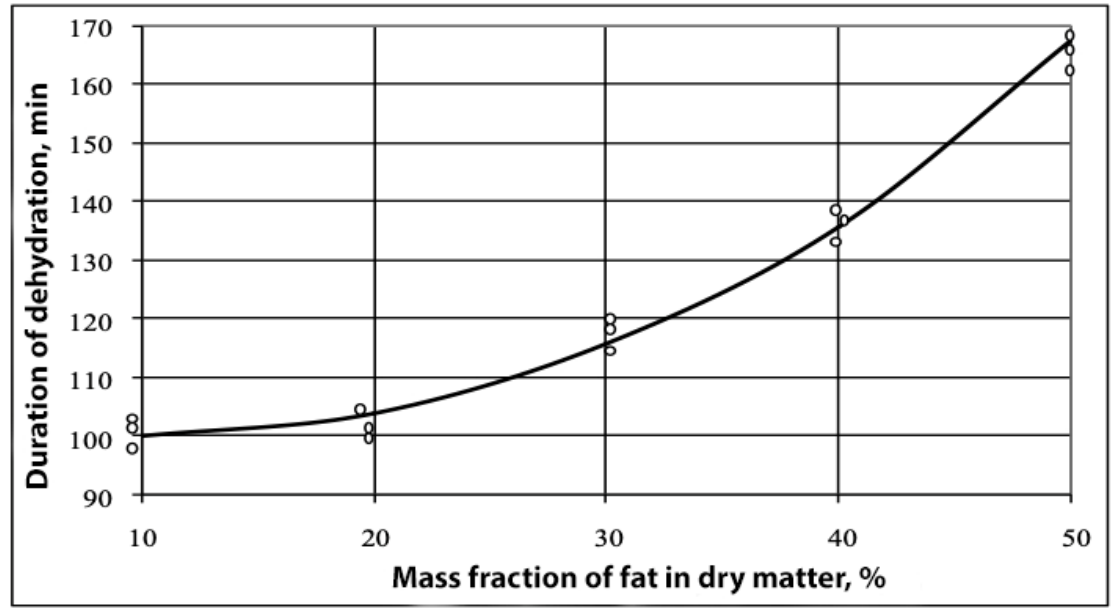

Fig. 3. The dependence graphs of the cheese drying time on the mass fraction of fat

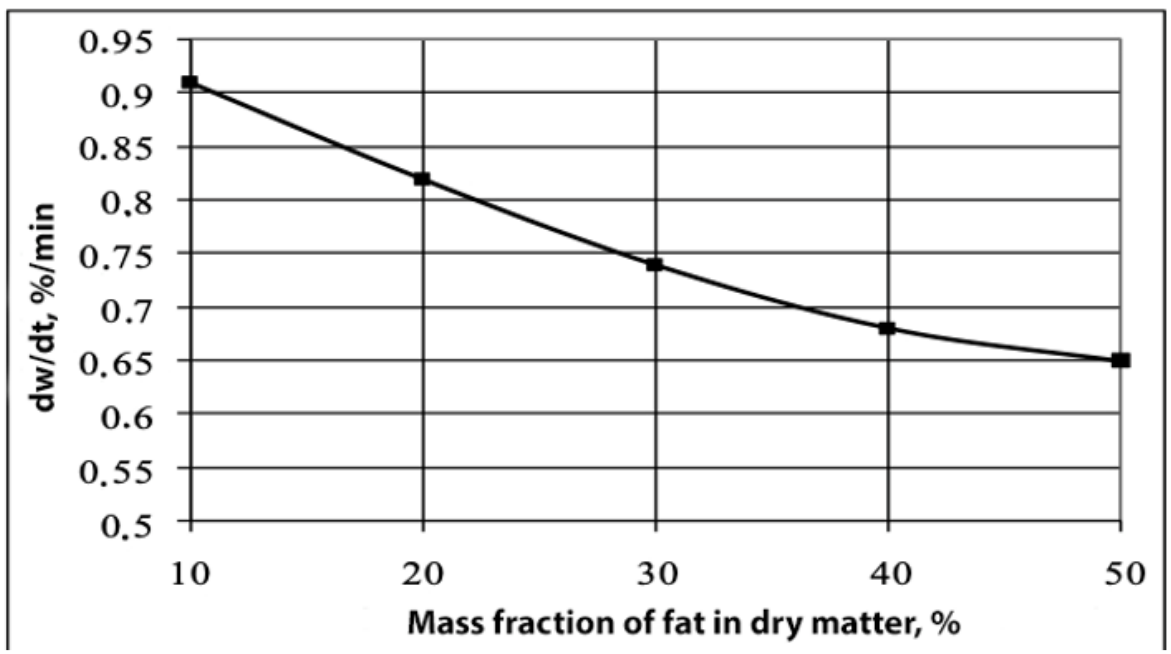

Fig. 4. The dependence of the cheese drying speed on the mass fraction of fat

It was found that for cheeses, which have the mass fraction of fat in dry matter in the range from 10 to $50 \%$, a change in the mass fraction of fat by $1 \%$ changes the duration of dehydration by 4.25 minutes and the drying rate by $0.0065 \% / \mathrm{min}$.

Further, studies were conducted to analyze the effect of salt content on the vacuum drying process.

Such factors as the duration of salting, the moisture content of the product, its geometric characteristics, concentration and temperature of the salt brine have influence on the content of solt component in cheeses. For cheeses "Rizhskiy", "Gollandskiy" and "Kostromskoy" salt content accounts for 1.5-2.5; 2-3.5 and $1.5-2.5 \%$ respectively.

When cheese is immersed in a concentrated or saturated solution of table salt, the difference in the concentrations of the aqueous phases of the cheese and brine promotes the salt to diffuse into the product and the aqueous phase of the cheese to migrate back to the brine. This diffusion process is characterized by a slow flow pattern. A simplified equation, that provides a fairly accurate definition of the salting degree (S) of cheese placed in brine, is written as follows [1]:

\footnotetext{
Corresponding author: ermolaevvla@ rambler.ru
}

$$
S=2 \cdot C \cdot \frac{A}{V} \cdot\left(\frac{D \cdot t}{\pi}\right)^{1 / 2}
$$

where $S$ is expressed in grams of salt per $100 \mathrm{~g}$ of water; $C$ is a concentration of brine, $g$ of salt per $100 \mathrm{~g}$ of water; $A$ is a surface area of cheese, $\mathrm{cm}^{2} ; V$ is a volume of cheese, $\mathrm{cm}^{3} ; t$ is a duration of salting cheese in salt brine, hour or day; $D$ is the specific coefficient of salt diffusion for a given cheese mass, $\mathrm{cm}^{2} / \mathrm{h}$ or $\mathrm{cm}^{2} /$ day.

When cheese is placed in salt brine, the latter is gradually saturated with the dissolved substances. In parallel, there occurs its slow dilution. On the other hand, the mass and size of the cheese heads after salting are less than before salting (the mass of cheese heads after salting is $96-98 \%$ of the original one).

These facts indicate that with the absorption of salt by the product, the moisture content in it simultaneously decreases. At the same time, part of the moisture that remains in the cheese takes on more energy-intensive forms of contact with dry matter. While the process of cheese ripening, moisture passes from a free to a bound form.

Figure 5 presents graphs of the cheese drying speed with different mass proportion of table salt. 
It was established that with an increase in the concentration of table salt within the same mass fraction of cheese moisture 53-55\%, a decrease in the rate of dehydration is observed. During a period of constant drying speed at a concentration of sodium chloride $1 \%$, the drying speed is $0.98 \% / \mathrm{min} ; 2 \%-0.8 \% / \mathrm{min} ; 3 \%$ $-0.72 \% / \mathrm{min} ; 4 \%-0.54 \% / \mathrm{min}$. This occurs because with an increase in salt concentration, moisture in the cheese goes into more energy-intensive connections.

The binding of table salt to moisture is confirmed with a decrease in the activity of cheese water. With an increase in salt concentration, the activity of water in cheeses decreases before and after drying (Table 1).

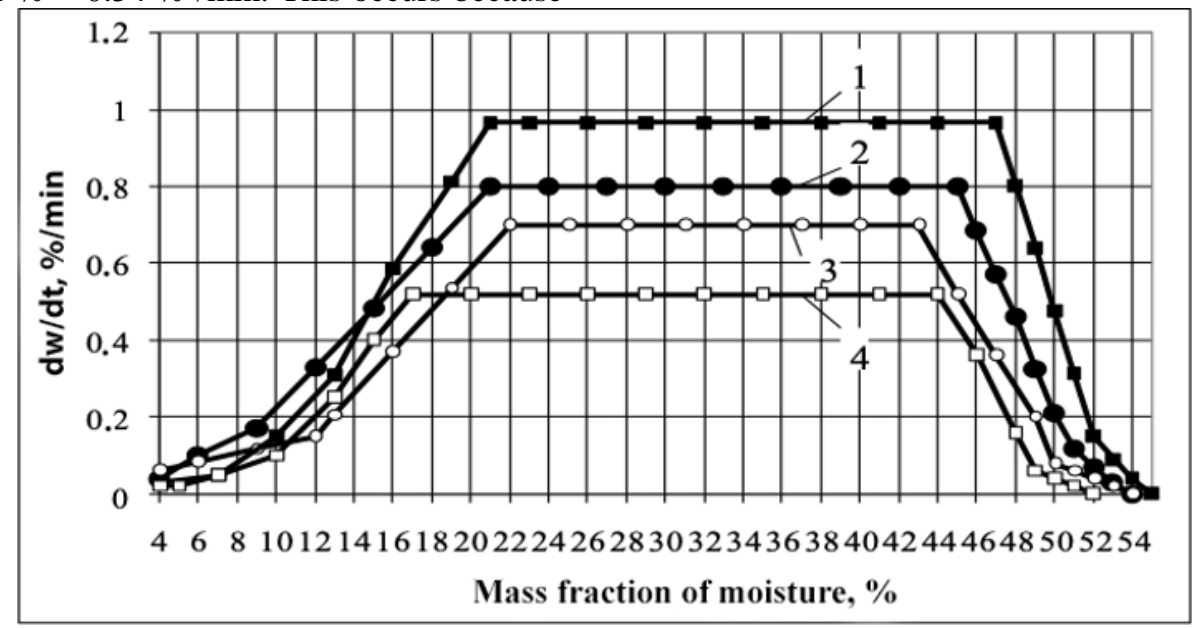

Fig. 5. The graphs of vacuum drying speed of cheeses with a concentration of salt: $1-1 \% ; 2-2 \% ; 3-3 \% ; 4-4 \%$.

Table 1. The water activity of cheese before and after drying, depending on the concentration of table salt.

\begin{tabular}{|c|c|c|c|c|}
\hline \multirow[b]{2}{*}{$\begin{array}{c}\text { Concentration } \\
\text { of table salt } \\
\text { in cheese, } \%\end{array}$} & \multicolumn{2}{|c|}{ Before drying } & \multicolumn{2}{|c|}{ After drying } \\
\hline & $\begin{array}{c}\text { Moisture } \\
\text { mass } \\
\text { fraction, \% }\end{array}$ & $\begin{array}{c}\text { water } \\
\text { activity }\end{array}$ & $\begin{array}{c}\text { Moisture } \\
\text { mass } \\
\text { fraction, \% }\end{array}$ & $\begin{array}{l}\text { water } \\
\text { activity }\end{array}$ \\
\hline 1.0 & 42 & 0.971 & 4.5 & 0.551 \\
\hline 1.5 & 42 & 0.962 & 4.7 & 0.486 \\
\hline 2.0 & 42 & 0.940 & 4.9 & 0.459 \\
\hline 2.5 & 42 & 0.924 & 4.5 & 0.432 \\
\hline 3.0 & 42 & 0.902 & 4.5 & 0.403 \\
\hline 3.5 & 43 & 0.877 & 4.7 & 0.389 \\
\hline 4.0 & 44 & 0.843 & 4.7 & 0.377 \\
\hline
\end{tabular}

It was found that with an increase in the concentration of table salt from 1 to $4 \%$, the water activity of cheese before drying changes by 0.131 ; after drying - by 0.174 . It should be noted that the activity of water decreases more with an increase in the concentration of table salt in cheeses over $2.5 \%$.

\section{Conclusion}

Thus, it was found that for cheeses with the same mass fraction of fat and moisture, the duration of the drying process is almost equal. The highest drying rate for cheeses is $0.8-1.05 \% / \mathrm{min}$. With increasing mass fraction of moisture in cheeses, the rate of moisture removal and the duration of the period of constant drying speed consequently increase.

It was found that with an increase in the concentration of table salt with the same mass fraction of cheese moisture in the range of 53-55\%, a decrease in the rate of dehydration is observed as well. With an increase in salt content in cheeses, a decrease in water activity is also established.

\section{References}

1. L. Xie, A.S. Mujumdar, Xiao-Ming Fang et al., Farinfrared radiation heating assisted pulsed vacuum drying (FIR-PVD) of wolfberry (Lycium barbarum L.): Effects on drying kinetics and quality attributes, Food and Bioprod. Proc., 102, 320-331 (2017)

2. V. King, R. Zall, Controlled low-temperature vacuum dehydration - a new approach for lowtemperature and low-pressure food drying, J. of Food Sci., 54(6), 1573-1579, 1593 (1989)

3. S. Devahastin, P. Suvarnakuta, S. Soponronnarit, A. Mujumdar, Comparative study of low-pressure superheated steam and vacuum drying of a heatsensitive material, Drying Technol., 22, 1845-1867 (2004)

4. L.Q. Yang, Dry sliding dehavior of a tizr-based alloy under air and vacuum conditions, J. of Mater. Engineer. and Perform., 28, 3402-3412 (2019)

5. J. Lope, A. Vega-Galvez, C. Bilbao-Sainz et al., Influence of vacuum drying temperature on: Physico-chemical composition and antioxidant properties of murta berries, J. of Food Proc. Engineer., 40(6), UNSP e12569 (2017)

6. L. Xie, A.S. Mujumdar, Fang Xiao-Ming et al., Farinfrared radiation heating assisted pulsed vacuum drying (FIR-PVD) of wolfberry (Lycium barbarum L.): Effects on drying kinetics and quality attributes, Food and Bioprod. Proc., 102, 320-331 (2017)

7. M. Rabeta, S. Lin, Effects of different drying methods on the antioxidant activities of leaves and berries of Cayratia trifolia, Sains Malaysiana, 44(2), 275-280 (2015) 
8. M. Rubinskienè, P. Viškelis, E. Dambrauskienè, J. Viškelis, R. Karklelienè, Effect of drying methods on the chemical composition and colour of peppermint (Mentha $\times$ piperita L.) leaves, ZemdirbysteAgricult., 102(2), 223-228 (2015)

9. M. Zdravko, N. Aleksandra, D. Stela, V. Radomir, Optimization of frozen wild blueberry vacuum drying process, Hemijska industrija, 69(1), 77-84 (2015)

10. A. Wojdylo, A. Figiel, K. Lech, P. Nowicka, J. Oszmianski, Effects of convective and vacuummicrowave drying on the bioactive compounds, color, and antioxidant capacity of sour cherries, Food and Bioproc. Technol., 7, 829-841 (2014)

11. Mu Yanqiu, Zhao Xinhuai, Liu Bingxin et al., Influences of microwave vacuum puffing conditions on anthocyanin content of raspberry snack, Int. J. of Agricult. and Biolog. Engineer., 6(3), 80-87 (2013)

12. A. Horszwald, H. Julien, W. Andlauer, Characterisation of Aronia powders obtained by different drying processes, Food chem., 141(3), 2858-2863 (2013)

13. Yuan-hui Li, Ya-ru Qi, Zhen-feng $\mathrm{Wu}$ et al., Comparative study of microwave-vacuum and vacuum drying on the drying characteristics, dissolution, physicochemical properties, and antioxidant capacity of Scutellaria extract powder, Powder technol., 317, 430-437 (2017)

14. L. Perea-Sanz, Microbial changes and aroma profile of nitrate dry sausages during vacuum storage, Meat Sci., 147, 100-107 (2019)

15. V.A. Ermolaev, Cheese as a Tourism Resource in Russia: The First Report and Relevance to Sustainability, Sustainability, 11, 5520 (2019)

16. V.A. Ermolaev, Missions of Russian Cheese Producers: Principal Components and Relevance for Rural Communities, Agricult., 10, 68 (2020)

17. S. Nile, S. Park, Edible berries: bioactive components and their effect on human health, Nutrit., 30(2), 134-144 (2014)

18. J. Kellogg, J. Wang, C. Flint, M. Lila et al., Alaskan wild berry resources and human health under the cloud of climate change, J. of Agricult. and Food Chem., 58(7), 3884-3900 (2010)

19. C. Bowen-Forbes, M. Nair, Y. Zhang, Anthocyanin content, antioxidant, anti-inflammatory and anticancer properties of blackberry and raspberry fruits, J. of Food Composit. and Anal., 23(6), 554-560 (2010)
20. S. Afrin, M. Gasparrini, T. Forbes-Hernandez et al., Promising health benefits of the strawberry: a focus on clinical studies, J. Agricult. Food Chem., 64(22), 4435-4449 (2016)

21. A. Artnaseaw, S. Theerakulpisut, C. Benjapiyaporn, Development of a vacuum heat pump dryer for drying chilli, Biosyst. Engineer., 105(1), 130-138 (2010)

22. B. Zecchi, L. Clavijo, J. Martínez Garreiro, P. Gerla, Modeling and minimizing process time of combined convective and vacuum drying of mushrooms and parsley, J. of Food Engineer., 104(1), 49-55 (2011)

23. U. Mannanov, Sh. Mamatov, B. Shamsutdinov, Research and study mode vacuum infrared drying vegetables, Austr. J. of Techn.l and Natural Sci., 3-4, 38-41 (2016)

24. M. Dalvi-Isfahan, Review on identification, underlying mechanisms and evaluation of freezing damage, J. of Food Engineer., 255, 50-60 (2019)

25. T. Li, Effect of E-polysine on K-carrageenan gel properties: phenology, water mobility, thermal stability and microstructure, Food Hydrocolloids, 95, 212-218 (2019)

26. T. Nicolai, Gelation of food protein-protein mixtures, Advan.s in Colloid and Interface Sci., 270, 147-164 (2019)

27. Y.Xu Amy, Effects of polysaccharide charge pattern on the microstructures of $\beta$-lactoglobulinpectin complex coacervates, studied by SAXS and SANS, Food Hydrocolloids, 77, 952-963 (2018)

28. K. Alba, W. Macnaughtan, A. Laws et al., Fractionation and characterisation of dietary fibre from blackcurrant pomace, Food Hydrocolloids, 81, 398-408 (2018)

29. O. Badaoui, S. Hanini, A. Djebli, H. Brahim, A. Benhamou, Experimental and modeling study of tomato pomace waste drying in a new solar greenhouse: Evaluation of new drying models, Renewable Energy, 133, 144-155 (2108)

30. H. Chen, C. Zhao, J. Li, S. Hussain et al., Effects of extrusion on structural and physicochemical properties of soluble dietary fiber from nodes of lotus root, Lebensmittel-Wissenschaft \& Technol., 93, 204-211 (2018)

31. Y. Guo, W. Liu, B. Wu, P. Wu, Y. Duan, Q. Yang et al., Modification of garlic skin dietary fiber with twin-screw extrusion process and, in vivo, evaluation of $p b$ binding, Food Chem., 268, 550-557 (2018) 